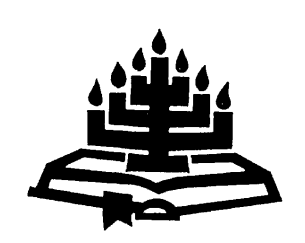

\title{
Die predikant wat houe uitdeel - die gemeente as teiken
}

\author{
C.J.H. Venter \\ Skool vir Kerkwetenskappe \\ Potchefstroomkampus \\ Noordwes-Universiteit \\ POTCHEFSTROOM \\ E-pos: kwscjhv@puk.ac.za
}

Abstract

A minister inflicting wounds - a congregation as target

In subject-related literature in the field of Practical Theology a certain emphasis is placed on studying the actions, spirituality and conduct of a minister. This article links up with this trend and attempts a closer investigation of the attitude and actions of a minister who unintentionally or intentionally wounds members of a congregation. In the article basis-theoretical perspectives from the Pastoral Epistles on the calling, requirements and spirituality of a minister are indicated. The metatheoretical research in this article is directed at investigating possible trends in contemporary society, the way in which a minister reacts to and copes with these trends and how his reaction may contribute to a situation where he hurts members of the congregation. This part of the investigation is followed by findings of established research on certain possible personality disorders that may contribute to a minister's acts and attitudes of wounding a congregation. Special focus is placed on narcissistic, histrionic and obsessive-compulsive personality disorders. Finally, practice-theoretical perspectives on guiding future pastors are provided - especially as a means of sensitising them to the possibility of their own approach and behaviour being experienced as negative and that of someone inflicting wounds. In the final instance, the congregant experiencing the wounds as well as the minister inflicting the wounds should still be regarded as objects of God's saving grace and the pastoral care of the community of faith. 
Opsomming

Die predikant wat houe uitdeel - die gemeente as teiken

Besondere aksent word in toepaslike Prakties-Teologiese vakliteratuur gelê op die bestudering van aspekte van die bedienaar se optrede, spiritualiteit en gedrag. Hierdie artikel wil daarby aansluit en nadere ondersoek instel na die bedienaar wat deur sy gesindheid en optrede gemeentelede bewustelik of onbewustelik verwond. Basisteoretiese perspektiewe word veral uit die Pastorale Briewe gebied op die roeping, vereistes en spiritualiteit van die bedienaar. Die metateoretiese ondersoek word veral gerig op die bedienaar se hantering van bepaalde tendense in die huidige kultuursituasie as moontlike aanleiding vir die geneigdheid om lidmate deur sy optrede te verwond. Hierna word gefokus op moontlike persoonlikheidsdisfunksies by die bedienaar wat kan veroorsaak dat sy optrede verwond. Daar word veral gefokus op narsissistiese, histrioniese en obsessief-kompulsiewe persoonlikheidsdisfunksies. Ten slotte word praktykteoretiese perspektiewe gebied op die begeleiding van toekomstige predikante - veral om hulle bewus te maak van die moontlikheid dat hulle aanslag en optrede ervaar kan word as negatief en dié van iemand wat wonde toedien. Die lidmaat wat verwond word, asook die bedienaar wat verwond, word egter ten slotte steeds beskou as voorwerp van God se genade en die herdelike sorg van die kerk.

\section{Oriëntering}

Wanneer Bybelse riglyne oor die persoon en persoonlikheid van 'n bedienaar van die Woord in gedagte gehou word, kom die volgende prentjie onwillekeurig in die gedagte op: iemand wat met nederigheid dien, be-dien, ondersteun en stut; iemand wat help om met empatie wonde te heel; iemand wie se persoon en belange ondergeskik is aan sy geroepenheid. Tradisioneel is bogenoemde ook die ideaalbeeld wat baie gemeentelede van hulle predikant het.

Tog is die situasie dat die teenoorgestelde meermale in die praktyk beleef word. In plaas van dienaar en be-dienaar wees, is die beeld wat gemeentelede van 'n predikant het, ongelukkig ook soms dié van iemand wat houe uitdeel, 'n onverbiddelike rigtingbepaler, 'n hoofbestuurder wat verwag dat sy bevele uitgevoer word, 'n rigiede afrigter wat bepaalde resultate opeis; 'n septerswaaier wat nie teenstand duld nie. Dan gebeur dit dat die beeld van die bedienaar as pastor, as vertrooster en heler van wonde erg versteur word, want dan is die bedienaar van die Woord nie iemand wat help om die wonde te verbind nie, maar word hy inderdaad iemand wat verwond, iemand wat houe uitdeel wat seermaak. 
Die titel van hierdie artikel hou in dat wetenskaplike navorsing onderneem word oor die bedienaar wat verwond. Hierdie navorsing word nie onderneem in 'n gesindheid om vinger te wys nie, maar in deernis en in begrip vir die gebroke werklikheid waarin sowel die bedienaar as die gemeente lewe 'n Doelwit met dié artikel is die bewusmaking van 'n sensitiewe probleem wat in kerke en in die bediening kan voorkom. Om hierdie rede is ook ' $n$ aanvullende artikel geskryf waarin gehandel word oor die bedienaar wat verwond word, die predikant as teiken (vgl. Kruger \& Venter, 2004:451-476).

Vir hierdie eerste artikel val die fokus op die bedienaar wat lidmate deur sy optrede verwond. Die motivering vir hierdie studie kan uit toepaslike literatuur nader aangedui word. In vakliteratuur word die fokus tans sterk geplaas op die persoon, handeling, gesindheid en persoonlikheid van die bedienaar (Lutzer, 1998; Greenfield, 2001; Kruger, 2000:2). In die Homiletiek word veral aandag gewy aan aspekte soos die gesindheid van die prediker (Kruger \& Venter, 2000:173-193), die spiritualiteit van die prediker (Montoya, 2000:1938; Dreyer, 2003:715-733) en ook op verwagtinge wat van die prediker gekoester word (Lutzer, 1998:15-20). Ten opsigte van prediking word gevra of die bedienaar self aangegryp is deur die Woord wat verkondig word in die kerk (Willhite, 2001:21-34; De Wet \& Venter, 2001:23-35). Hierdie is vrae wat selfs in artikels van meer populêre aard na vore kom (Tempelhoff, 2002:42; Jackson, 2002: 38-41).

In die lig van die motivering hierbo word ook hierdie ondersoek onderneem. Basisteoreties word gesoek na antwoorde op vrae soos die roeping van die bedienaar, die Skrifvereistes vir die bedienaar en ook aspekte soos spiritualiteit in die lewe van die bedienaar. Op metateoretiese vlak word sake ondersoek soos die invloed van die tydsgees as faktor wat kan bydra dat die bedienaar sy gemeente verwond of deur sy optrede "houe uitdeel". Nadere ondersoek word ook op metateoretiese vlak ingestel na die persoonlikheid van die bedienaar en na enkele persoonlikheidstipes wat geneig mag wees tot verwonding vanweë moontlike psigologiese disfunksies. Met hierdie ondersoek word nie gesuggereer dat alle bedienaars wat verwond en houe uitdeel sodanige persoonlikhede het nie, ook nie dat sodanige bedienaars nie die tydsgees reg kan beoordeel nie en daarom hulle lidmate krenk en verwond. Binne die beperkte omvang van 'n artikel moet die behandeling van toepaslike materiaal begrens word. Ten slotte word enkele praktykteoretiese riglyne gebied vir die begeleiding van toekomstige predikante, hulp aan verwonde gemeentelede en ook aan 'n bedienaar wat bewustelik of onbewustelik sy lidmate verwond. 
Die metode wat gebruik word, is dié van analise, interpretasie en sintese van toepaslike data uit resente literatuur.

\section{Basisteoretiese perspektiewe op die bedienaar wat verwond en houe uitdeel}

In hierdie betrokke onderafdeling sal veral die Pastorale Briewe ontgin word met die oog om die basisteoretiese gegewens byeen te bring. Die motivering hiervoor is dat die Pastorale Briewe van die mees sentrale openbaringsflitse bevat oor die roeping, persoon, optrede, vereistes en werk van die bedienaar.

\subsection{Die roeping van die bedienaar}

Die rede waarom hier kortliks ingegaan word op die roeping van die bedienaar is om 'n moontlike gesindheid van verwonding by die bedienaar te toets aan Skrifgegewens in verband met 'n bedienaar se roeping.

In die Pastorale Briewe kom roeping ter sprake veral in vyf gedeeltes, naamlik in 1 Timoteus $1: 18$ en 2:5-7, in 2 Timoteus 1:911 en 2:1-2 asook in Titus 1:4-5. Die begrip roeping word in die gedeeltes agtereenvolgens weergegee met die volgende: opdrag gee, aanstel (drie keer) en toevertrou. In Grieks word dieselfde werkwoord of 'n vervoeging daarvan telkens gebruik (tithème). Hierdie begrip word verder nog 17 keer in die Nuwe Testament gebruik, waarvan slegs een keer weer deur Paulus, naamlik in 1 Korintiërs 10:27.

Die letterlike konnotasie van roeping is om voor iemand neer te sit (soos byvoorbeeld voedsel) of ook om eenkant te sit, af te sonder (vgl. Quinn \& Wacker, 2000:141). Dieselfde uitdrukking word deur Jesus in die laaste kruiswoord gebruik as Hy uitroep: Vader in $U$ hande gee ek my Gees oor (Luk. 23:46). So dra Paulus en Barnabas ook die ouderlinge wat hulle aangestel het aan die Here op (Hand. 14:23). Dit is redelik om hieruit af te lei dat roeping te doen het met afsondering tot 'n spesifieke bediening. God se aksie staan hierin voorop.

Dit is verder opvallend dat - in al vyf die gedeeltes waarin roeping sentraal staan - die fundering van die roeping lê in die versoening wat God bewerk het. In volgorde dui die volgende uitdrukkings in die roepingsgedeeltes God se versoeningswerk so aan: sondaars te red, Homself as losprys gegee, verskyning van ons Verlosser, genade in Jesus Christus en Jesus Christus ons Verlosser. 
Juis om hierdie rede is dit ook nie vreemd nie dat die doel van die roeping die toepassing en verkondiging van die evangelie van versoening is: in die lewe van die bedienaar self (om die goeie stryd te kan stry -1 Tim. 1:18), as prediker en apostel (1 Tim. 2:7; 2 Tim. 1:4), bekwaam om ander te leer (2 Tim. 2:2), met die gesonde leer te vermaan (Titus 1:5).

Die belangrike afleiding uit hierdie verkenning is dat die roeping van die bedienaar die volgende inhou: afsondering deur God vir 'n baie spesifieke taak, naamlik die bediening van die versoeningswerk van God in Jesus Christus aan sy gemeente.

\subsection{Die vereistes vir die bedienaar (1 Tim. 3:3-7 en Titus 1:6-9)}

Die lys vereistes vir die bedienaar kan onder verskillende hoofde ingedeel word, naamlik ten opsigte van die bedienaar se gesin, sy karakter en sy optrede (vgl. Bassler, 1996:63 e. v.) en ten opsigte van die bedienaar se pastorale optrede, gedrag, karakter en optrede na buite (Armstrong, 1990:127-134; Venter, 1976:77).

Vir die doeleindes van hierdie artikel sal 'n seleksie van vereistes verken word wat spesifiek op die tema toegespits word. Die vraag is: is daar vereistes wat deur die nakoming of nie-nakoming daarvan verwonding van die kant van die bedienaar kan bevorder of voorkom?

'n Kardinale vereiste is dat die bedienaar nie 'n rusiemaker moet wees nie: iemand wat byvoorbeeld hard op 'n bejaarde toeslaan in 'n vermaning nie (1 Tim. 5:1). Letterlik hou hierdie vereiste in dat die bedienaar eerder 'n geveg sal vermy. Wat hierdie rusie, wat vermy moet word, inhou word duidelik uit die wyer verband. Rusie ontstaan uit dwase en sinlose strydvrae (2 Tim. 2:23). Die verdere vereiste in Titus 1:7 dat die bedienaar nie opvlieënd behoort te wees nie, hou in dat selfbehaging aan die wortel van verwonding lê en rusie en opvlieënde optrede tot gevolg het.

Wat staan dan teenoor rusie, twis en opvlieëndheid? Sowel in Titus $1: 8$ as in 1 Timoteus 3:2 word die vereiste van selfbeheersing gestel. Hoewel twee verskillende Griekse woorde meermale gebruik word vir selfbeheersing, beteken hulle inhoudelik dieselfde. Selfbeheersing is by uitstek die vrug van die Heilige Gees in die lewe van 'n bedienaar en dit word bewerk deur die versoeningswerk van Christus (vgl. Towner, 1994:227). Dit is opvallend dat in die uiteensetting van die vrug van die Gees in die lewe van 'n gelowige (Gal. 5:22), die begrip selfbeheersing gebruik word, maar dan klimakties 
heel laaste, as 't ware as die hoogste dimensie van die werking van die Gees in die hart van 'n gelowige (vgl. Dreyer, 2003:725).

Vervolgens word gelet op die gebruik van die metafoor van die bedienaar se huisgesin (1 Tim. 3:4 en Titus 1:6). Die metafoor word deur Paulus direk betrek op die bedienaar se optrede in die gemeente, die huisgesin van God (1 Tim. 3:15). Soos 'n bedienaar in sy gesin optree, so sal hy optree in God se gesin. 'n Dimensie wat belangrik is vir die tema van hierdie artikel, is dat die beeld van die gesin veral verhouding uitdruk. In 'n sekere sin is verhoudingvorming en -onderhouding die kern van die saamlewe in 'n gesin en in 'n gemeente. Wanneer ander mense - in dié geval lidmate - die teiken van verwonding word, gebeur dit waar die verhouding geskaad, verbreek of verwaarloos word. Juis om hierdie rede gee Paulus ook direkte voorskrifte in 1 Timoteus 5:1-2: 'n Bejaarde moet nie deur vermaning verwond word nie, maar soos in die verhouding van 'n seun tot 'n vader vermaan word, 'n ou vrou soos seun teenoor moeder, en jongmense soos broer teenoor broer of broer teenoor suster (vgl. Stott, 1997:119).

Teenoor ' $n$ gesindheid om te verwond, om houe uit te deel, staan verder ' $n$ gesindheid van vriendelikheid (1 Tim. 3:3), lief vir wat goed is (Titus 1:8) en onberispelike gedrag (1 Tim. 3:2; Titus 1:6), dit wil sê, sodanige gedrag dat (letterlik) niemand 'n hand op die bedienaar kan lê nie of 'n vinger na die bedienaar kan wys nie. Vriendelikheid, liefde vir die goeie en onberispelike gedrag is die uiterlike bewyse van die innerlike werking van die Heilige Gees in die lewe van 'n dienaar.

\subsection{Die spiritualiteit van die bedienaar}

Die spiritualiteit van die bedienaar word dikwels ook in navorsing betrek (vgl. Clements, 1998:10-17; Kim, 1997:1-10).

Vir ons doeleindes word onder die term spiritualiteit verstaan die lewe van die bedienaar coram Deo (Louw, 1997:16-17). Dié term hou in dat die lewe van die bedienaar in al sy fasette 'n lewe voor die oë van God is (Venter, 1999:189). Die omskrywing hou verband met Bybelse uitdrukkings soos godsvrug, vroomheid, geloof, liefde, selfbeheersing, heiligheid en ander toepaslike begrippe in die Nuwe Testament. In die Pastorale Briewe word veral twee uitdrukkings gebruik om die bedienaar se spiritualiteit te omskryf. Die uitdrukking eusebeia (godsvrug) kom onder andere voor in 1 Timoteus 4:7-8 en die uitdrukking hagneia (heiligheid) onder andere in 2 Timoteus 1:9. 


\section{- Die uitdrukking godsvrug (eusebeia)}

In Engelse vakliteratuur word dié begrip gebruik vir "man's relation to God in a godly manner" (Bauer, 1979:326). Stott (1997:155) beskou godsvrug as die allereerste kenmerk van 'n getuie van Christus.

\section{- Die uitdrukking heilig (hagneia)}

Hierdie begrip verwoord veral die persoonlike toewyding van die bedienaar aan God - "a lifestyle that is visibly different. It is a life lived in close relationship with God" (Towner, 1994:163).

'n Nadere beskouing van die begrippe godsvrug en heiligheid bring aan die lig dat die inhoud hiervan 'n lewe in toewyding aan God is. Hierdie lewe in toewyding word sigbaar in die gedrag en optrede van die bedienaar, ook in sy bediening van gemeentelede.

\subsubsection{Die Gees as outeur van spiritualiteit}

Die verklaring van begrippe wat godsvrug verwoord, bring ons by die vraag wat die bron van die spiritualiteit van die bedienaar inhou. In hierdie verband word 2 Timoteus $1: 7$ as toepaslik beskou. In hierdie vers word die teenoorgestelde beskryf van lafhartigheid in die bediening.

God het ons nie 'n gees van lafhartigheid gegee nie, maar van krag, liefde en selfbeheersing. Hierdie drie gawes kan beskou word as die hart van die bedienaar se spiritualiteit. Hierbo is reeds aangetoon dat selfbeheersing 'n bewys is van die werking van die Heilige Gees in die bedienaar se lewe en optrede. Die krag waarvan hier sprake is, is God se krag wat in die bedienaar werk en hom in staat stel om teëstanders te weerlê, God se boodskap vrymoedig te verkondig en om lyding te verdra wat op die bedienaar se weg mag kom (Bassler, 1996:130).

Inhoudelik hou die begrippe krag, liefde en selfbeheersing verband met 2 Timoteus 2:24 waar gestel word dat 'n bedienaar van God kwaad moet kan dra. Die uitdrukking wat hier gebruik word, het nie eerstens die lydelike verdra van aangedane kwaad op die oog nie, maar eerstens ' $n$ dra van die kwaad sonder om gegrief te wees en juis daarom ook 'n verdra van liefdeloosheid (Stott, 1997:78). "The word denotes an attitude of patient forbearance toward those who are in opposition" (Rienecker, 1980: 297). Dit is opvallend dat 'n gesindheid soos hierbo beskryf, lynreg staan teenoor die gesindheid van rusiemaak in die begin van 2 Timoteus 2:24. 


\subsubsection{Spiritualiteit en gesag in die bediening}

'n Bedienaar wat andere verwond, seermaak of krenk, mag meermale verband hou met 'n skeefgetrekte siening van gesag in die bediening. Lê gesag in die persoon van die bedienaar? Hoe behoort gesag in die bediening na vore te kom? In watter gesindheid behoort gesag uitgeoefen te word? Hierdie is almal vrae wat verband mag hou met die optrede van 'n bedienaar wat houe uitdeel, krenk of verwond.

Twee gedeeltes uit die Pastorale briewe mag lig werp op hierdie vrae.

In 1 Timoteus 4:6 word ' $n$ bedienaar aan wie die evangelie toevertrou is, 'n dienaar van Jesus Christus genoem. In 2 Timoteus 2:24 word ' $n$ bedienaar ' $n$ slaaf van Jesus Christus genoem. Dienaar hou dus letterlik in: nederige tafeldiens. Slaaf hou in dat die bedienaar in totale afhanklikheid van God lewe. Die algehele afhanklikheid van die dienaar of slaaf is gerig op die algehele beslaglegging deur die Kurios (Quinn \& Wacker, 2000:699). 'n Slaaf het geen gesag in sy persoon nie. Sy woord het gesag mits dit die woord van sy eienaar is wat aan medeslawe gebring word. Die gesag van die woord van die slaaf word in hierdie verse uitgedruk deur die herhaalde genitiefverbinding: dienaar van Christus, slaaf van Christus, die Kurios. Sy Koning, Jesus Christus self, verleen gesag aan hierdie slaaf se woord.

Dit kan dus afgelei word dat die woord wat 'n bedienaar bring, wel gesag het as dit die Woord van die Kurios is wat oorgedra word. 'n Bedienaar het geen gesag in sy persoon nie. Indien 'n bedienaar die gesag wat aan die Woord toekom, vir sy persoon opeis, kan verwonding plaasvind.

\subsubsection{Spiritualiteit en die oefening van die spiritualiteit van die bedienaar}

\section{- Selfvoeding en gemeentevoeding}

In 1 Timoteus 4:6 word 'n verband gelê tussen die bedienaar se selfvoeding en sy voeding van die gemeente uit die Woord. "As jy hierdie dinge aan die broers voorhou, sal jy 'n goeie dienaar van Christus Jesus wees wat jouself voed met die woorde van die geloof en die goeie leer waarvan jy 'n aanhanger geword het." Dit gaan hier veral om die twee uitdrukkings voorhou en jouself voed. In Grieks word twee praesens partisipia in een sin gebruik vir voorhou en vir selfvoeding. Hierdie gebruik van die twee praesens partisipia 
bymekaar, hou in dat die een aksie nie noodwendig chronologies volg op die ander aksie nie. Voorhou en voed staan in 'n voortdurende wisselwerking met mekaar. Terwyl die bedienaar die Woord aan die gemeente voorhou, word die bedienaar self gevoed. Aan die ander kant: 'n bedienaar kan die Woord nie aan die gemeente voorhou, indien selfvoeding nie eens plaasgevind het nie (vgl. Venter, 1999:187-202).

Opregte omgang met die Woord en groei deur die Woord is ' $n$ kardinale moment in die oefening van spiritualiteit. lemand wat self vol is van God se Woord, verwond nie maklik nie. lemand wat vervul is met God se Woord, sal nie maklik die kudde wat aan hom toevertrou is, krenk met sy woorde en optrede nie.

\section{- Gebed}

In die Pastorale Briewe word die bedienaar telkens opgeroep om te bid. Vir ons doeleindes word 2 Timoteus 1:3(c) en 5(a) as toepaslik beskou. In hierdie verse word Paulus se gebed en die diepste vlak van Timoteus se spiritualiteit (sy opregte geloof) met mekaar verbind. In sy gebed herinner Paulus homself aan die ongeveinsde geloof van Timoteus. So verbind Paulus sy eie gebed aan die kern van Timoteus se spiritualiteit, sy opregte geloof. Dit is opvallend dat as Paulus praat van sy eie diens aan God, dan stel hy dat hy God met 'n skoon gewete dien - in ware spiritualiteit. As hy vir Timoteus bid, dank hy vir Timoteus se opregte geloof. 'n Skoon gewete en 'n opregte geloof is die diepste innerlike openbaring van 'n ware spiritualiteit. Die feit dat bedienaars God dank vir dit wat hulle as 'n suiwer spiritualiteit in mekaar waarneem, is die diepste uiterlike openbaring van egte spiritualiteit wat langs die weg van gebed deur die Heilige Gees gewerk word.

\section{Samevatting van basisteoretiese resultate}

- Die roeping van die bedienaar hou in dat God hom roep en afsonder vir 'n spesifieke taak op 'n spesifieke plek.

- Die roeping van die bedienaar rus in die versoeningswerk van Jesus Christus.

- Teenoor 'n rusiemakerige gesindheid by die bedienaar staan die vereistes van selfbeheersing, verhoudingskepping, vriendelikheid, onberispelike gedrag, godsvrug en heiligheid: kortom 'n lewe in die teenwoordigheid van God.

- Van die belangrikste dimensies in die beoefening van spiritualiteit is ' $n$ sistematiese, gefokuste en biddende omgang met die Woord en vanuit 'n persoonlike omgang met God. Hierin moet die 
wisselwerking tussen die bedienaar se selfvoeding en die voeding van die gemeente uit die Woord 'n kardinale plek inneem.

- Egte spiritualiteit bestaan in 'n opregte geloof in God en in 'n skoon gewete voor God Langs die weg van gebed skenk die Heilige Gees dit aan God se bedienaars.

\section{Metateoretiese perspektiewe op die bedienaar wat verwond}

In hierdie onderafdeling word veral aan twee aspekte aandag gegee, aspekte wat kan aanleiding gee dat die bedienaar houe uitdeel, verwond en seermaak. Hierdie twee aspekte is die moontlike invloed van die huidige kultuurpatroon en 'n bepaalde persoonlikheidstruktuur by die bedienaar.

\subsection{Die rol van huidige samelewingstendense in die moontlike negatiewe optrede van die predikant}

Samelewingstendense word meermale beskryf as die hedendaagse kultuurpatrone (Kulturgestalt) wat verklaar word as "... the interpretative and coping mechanism of society. It is the way in which people understand themselves, their world and the appropriate interaction with one another and with the world they live in" (Rossouw, 1993:894; vgl. Jang, 2003:44). Hierdie kultuur word genoem die postmodernisme en dit staan teenoor die vroeëre modernisme. Waar hierdie twee kultuurtendense langs mekaar gestel word, kom die volgende verskille na vore:

\section{Kultuurtendense - die modernisme en die postmodernisme} (vgl. Cilliers, 2004:27; Jang, 2003:44)

\begin{tabular}{|l|l|}
\hline Die modernisme & Die postmodernisme \\
\hline $\begin{array}{l}\text { Die modernisme was aanmatigend in } \\
\text { die sekerheid waarmee antwoorde } \\
\text { verskaf is. }\end{array}$ & $\begin{array}{l}\text { Die postmodernisme is soekend na } \\
\text { antwoorde. }\end{array}$ \\
\hline $\begin{array}{l}\text { Die modernisme het gedink dat dit } \\
\text { bykans al die antwoorde op vraag- } \\
\text { stukke het. }\end{array}$ & $\begin{array}{l}\text { Die posmodernisme stel eerder vrae } \\
\text { as om finale antwoorde te gee. }\end{array}$ \\
\hline $\begin{array}{l}\text { Die modernisme het vir baie (óók vir } \\
\text { predikante) vaste sekerhede en waar- } \\
\text { hede gebied. }\end{array}$ & $\begin{array}{l}\text { Die postmodernisme progageer relati- } \\
\text { wisme en subjektiwisme en is agter- } \\
\text { dogtig teenoor mense wat finale } \\
\text { antwoorde bied. }\end{array}$ \\
\hline
\end{tabular}


Prakties kan bogenoemde aspekte die volgende reaksies by baie mense na vore bring: objektiewe waarheid word verwerp, gesag word met skeptisisme bejeën, moraliteit vervaag, die soek na die transendente kom nooit tot 'n einde nie. Die Drie-enige God word as een van baie gode beskryf en Jesus Christus word nie as die enigste Saligmaker beskou nie (vgl. Johnston, 2001:26 e.v.) Voorts is daar 'n soeke na gemeenskap en die ervaring van nabyheid. Die Bybel word nie langer aanvaar as die gesagvolle Woord van God nie en is een van meer boeke wat gebruik kan word in die godsdiens.

Baie predikante het opgegroei in ' $n$ tydvak van modernisme. Van die vraagstukke wat toe hanteer moes word, was byvoorbeeld Skrifkritiek en nie soseer die siening dat die Skrif een van meer gesaghebbende boeke is nie. Dieselfde geld vir die gesag van die predikant. In die vroeëre era was predikante gesagsfigure bloot omdat hulle bedienaars van die Woord was. Vandag word gesag bevraagteken en sterk verbind aan professionaliteit. Die waarheid dat gesag verbind moet word met en gesetel is in die Woord wat verkondig word - en nie gesetel is in die bedienaar as persoon nie kom vandag inderdaad sterk na vore!

Indien hierdie tendense nie herken en beoordeel word nie, kan dit lei tot ' $n$ identiteitsprobleem by die bedienaar. Dan worstel hy met vrae soos: Wat is my roeping in 'n tyd van postmodernisme? Waarom luister baie gemeentelede nie (meer?) na wat gepreek word nie? Waarom word sommige sinodebesluite bloot geïgnoreer of nie as van belang geag nie? Waarom beskou mense preke steeds as rasionele uiteensettings met min wat ervaar en toegepas kan word in die praktyk? (vgl. Kruger, 2004:9-12).

Op hierdie tendense en vrae kan 'n bedienaar verskillend reageer. Die reaksie sou kan wees: óf ignoreer die vrae van die postmodernisme, óf gaan op in die postmodernisme, óf beantwoord die tendense van die postmodernisme met rigiditeit en aggressie en 'n leef in die verlede in plaas van leef uit die verlede in vandag se tyd met al sy vrae. Vorster (1999:105 e.v.) dui aan dat daar wins en verlies is vir kerke en vir die Praktiese Teologie in die uitvloeisels van die postmodernisme. Die wins van die postmodernisme is onder andere dat klem gelê word op persoonlike spiritualiteit en persoonlike beoefening van godsdiens. So word ruimte geskep om godsdiens nie net te hoor nie, maar ook te ervaar - juis in teenstelling tot formalisme in die godsdiens en oordrewe institusionalisme in die kerklike lewe. Om hierdie rede word die plaaslike kerk ook as van groter belang geag as kerklike 
vergaderings. Die outoritêre uitoefening van gesag word krities bejeën. 'n Predikant kan byvoorbeeld met aggressie en rigiditeit reageer op die element van onsekerheid wat deel vorm van die huidige kultuurpatroon. Wanneer die predikant dan byna krampagtig vashou aan vaste vorme wat in die verlede sonder enige aanpassing toegepas kon word, kan lidmate ervaar dat daar nie genoegsame begrip is vir hulle vrae en onsekerheid nie. As die predikant se houding en optrede ongeduld en min begrip vir lidmate se twyfelvrae toon, ervaar gemeentelede dit dikwels dat die predikant hulle wil "bykom" met onversetlike en geykte sienings en uitsprake.

\subsection{Die persoonlikheid van die bedienaar as aanleidende oorsaak dat hy houe uitdeel en gemeentelede verwond}

Die vraag moet vooraf gestel word: wat word verstaan onder menslike persoonlikheid? Kruger (2000:82 e. v.) behandel die problematiek om persoonlikheid te definieer. Hierin sluit hy aan by sowel die nomotetiese as die idiografiese rigtings van persoonlikheidsnavorsing in die Psigologie. Hy definieer persoonlikheid dan soos volg: "Persoonlikheid het te doen met die vaste denk- en gedragspatrone wat min of meer deurlopend by 'n persoon voorkom, wat aan hom 'n eie, unieke en uitkenbare identiteit gee ..." (Kruger, 2004:21). Emery en Oltmanns (1999:241) stel: "[personality is the combination] of persistent traits or characteristics that, taken as a whole, describe a person's behaviour". Albei outeurs beklemtoon deurlopende of vaste trekke wat 'n eie identiteit bied en waarvolgens mense optree.

Dit is reeds vroeër in hierdie artikel gestel dat nie alle bedienaars met ' $n$ bepaalde persoonlikheid beskou moet word as potensiële verwonders nie. Daar is in die kerklike bediening nog veel meer faktore wat daartoe aanleiding kan gee dat predikante gemeentelede verwond, in plaas daarvan dat hy hulle met die Woord bedien. Gemeentelede met ' $n$ bepaalde persoonlikheid kan ook self aanleiding gee tot hulle eie verwonding. Predikante kan byvoorbeeld self veronreg voel deur 'n lidmaat of kerklike vergadering en is dan geneig om ander bedienaars te wil verwond. 'n Bedienaar se persoonlike verhouding met God kon verkil het of sy huweliksverhouding kon in 'n krisis beland het en so gelei het tot die neiging om te verwond of houe uit te deel.

Die ander kant van die neiging om te verwond, selfs te krenk moet egter ook belig word. Kruger (2004:6) betoog dat ook bedienaars soos enige ander persoon - vasgevang kan wees in ' $n$ on- 
toereikende of swak aangepaste eie persoonlikheid wat 'n struikelblok in die bediening kan wees en dikwels vir jare ongehinderd voortduur. Op hierdie wyse kan talle lidmate verwond word. Die term wat vir 'n swak aangepaste persoonlikheid in psigologiese literatuur gebruik word, is persoonlikheidsafwyking of -disfunksie (personality disorder). Hiermee word bedoel "inflexible and maladaptive patterns of personality, that begins by early adulthood and result in either social or occupational problems or distress to the individual" (Emery \& Oltmanns, 1999:241). Kruger (2004:22) ontleed persoonlikheidstrekke wat na vore kom ten opsigte van geslotenheid en openheid in die hantering van nuwe ervarings. Persoonlikheidsafwyking sou dan op 'n kontinuum óf ver links (geslotenheid) óf ver regs (openheid) registreer, terwyl 'n goed aangepaste persoonlikheid redelik na aan die middel op die kontinuum tussen geslotenheid en openheid lê. In hierdie opsig moet ook die navorsing van Nel (2001:13-42) as van besondere waarde beskou word. Hy fokus spesifiek op die invloed van persoonlikheid op die prediking. Hierin behandel hy onder andere sake soos die persoon van die prediker, persoonlikheid en persoon, persoonlikheidsontwikkeling en persoonlikheidstipes. Hy kom tot die gevolgtrekking dat persoonlikheid kommunikeer. Juis hierdie bevinding van $\mathrm{Nel}$ (her)beklemtoon die belangrikheid van navorsing oor die persoonlikheid van die bedienaar wat sy gemeente(lede) verwond. 'n Disfunksionele persoonlikheid kan kommunikasie in die bediening blokkeer en daartoe lei dat die bedienaar in sy prediking voortdurend houe uitdeel, die gemeente verwond of selfs krenk.

In toepaslike vakliteratuur word ook van verskillende persoonlikheidstipes gepraat. Lutzer (1998:61) noem byvoorbeeld vier tipes persoonlikhede by wie uitbranding kan voorkom, naamlik by die persone wat sterk gerig is op die goedkeuring deur ander, by die werkolis, by die passiewe slagoffer en by persone met 'n sogenaamde messiaskompleks.

Wie probeer om die profiel van 'n predikant met 'n bepaalde disfunksionele persoonlikheid te omlyn, begeef hom of haar op die terrein van die psigopatologie. Dit is van belang dat persoonlikheidsafwykings tans veral deur die gebruik van die DSM-IV-TR2000 Handleiding ondersoek word. Hierdie afkorting staan vir Diagnostic and Statistical Manual of Mental Disorders-IV. Die handleiding is die standaardriglyn waarvolgens psigoloë in Amerika hulle diagnoses maak. Die DSM-IV is saamgestel deur die Amerikaanse Psigiatriese Assosiasie (APA) en berus op omvattende empiriese ondersoeke en voortgaande navorsing (Venter, 2003:42). Persoonlikheidsafwykings word in die DSM-IV-ondersoek in drie 
hoofgroeperinge verdeel (Emery \& Oltmanns, 1999:242). Groep A word saamgestel deur paranoïede, skisoïede en skisotipale disfunksies. Groep B word gevorm deur antisosiale, grenslyn(borderline), histrioniese en narcissistiese disfunksies en groep C deur a-sosiale (avoidant), oorafhanklike en obsessief-kompulsiewe tipes.

Uiteraard kan nie op al hierdie verdelings in besonderhede ingegaan word nie. 'n Seleksie word dus gemaak wat moontlik van toepassing mag wees - wat persoonlikheid betref - op die predikant wat die gemeente as teiken neem om hulle te verwond.

\section{- Paranoïede persoonlikheidsafwyking}

Die kenmerke in hierdie afwyking is onder andere die volgende: buitengewone agterdog ten opsigte van ander se motiewe en optrede. So 'n persoon is gou om aanstoot te neem en selfs aggressief of vyandig op te tree. Veral van belang is dat so ' $n$ persoon 'n meningsverskil as 'n persoonlike aanval op sy reputasie of karakter beskou, terwyl omstanders dit glad nie so beskou nie. Hy reageer dan vinnig met woede of 'n teenaanval (vgl. Greenfield, 2001:158-159). Die gevolg is seermakende of krenkende optrede en gevolglike verwonding.

Moontlike geprojekteerde manifestasies van die optrede van 'n predikant met hierdie afwyking kan die volgende persepsies wees:

- Niemand op die kerkraad kan vertrou word nie.

- Ek is seker dat gemeentelede met 'n vendetta teen my besig is.

- Ouderling A het my nie vriendelik gegroet nie - hy voer iets teen my in die mou.

- Broeder B verskil van my standpunt. Dit is niks anders as ' $n$ persoonlike aanval op my as bedienaar nie.

\section{- Die narsissistiese persoonlikheidsdisfunksie}

Hierdie persoon word herken aan minstens vyf van die volgende patrone: 'n gevoel van grootsheid (grandiose) en eie belangrikheid (oordryf eie vermoë en kundigheid); 'n preokkupasie met fantasieë van mag, sukses en eie briljantheid; behoefte aan buitensporige bewondering; eksploiteer ander om eie persoonlike doelwitte te bereik; gebrek aan empatie (kan nie identifiseer met die gevoelens en behoeftes van ander nie); arrogant en hooghartig in gesindheid en optrede (Greenfield, 2001:136). 
Moontlike geprojekteerde manifestasies van die optrede van 'n predikant met dié afwyking kan die volgende gevolge inhou:

- Die sogenaamde messiaskompleks hou verband met trekke wat hierbo genoem is en kan tot uitdrukking kom in die volgende gedagtes of persepsies van 'n bedienaar:

- Ek, met my vermoë en standvastigheid, is geroep om die kerk weer terug te lei na die waarheid. Self moet ek beskou word as die groot redder - of as die groot martelaar wat ly vir die waarheid.

- As mense nie dikwels praat oor my preke nie, kan hulle 'n goeie preek nie waardeer nie.

- Ek benader hartseermense pastoraal sterk op intellektuele vlak. Hulle emosies maak my ongemaklik.

- Ek is die kundige en ek - en niemand anders nie - neem besluite vir die kerk.

\section{- Die histrioniese persoonlikheidsdisfunksie}

Mense met hierdie disfunksie word herken aan die volgende: 'n deursigtige patroon om aandag te soek; hulle floreer as hulle die middelpunt van 'n gesprek of vergadering is; hulle is selfgesentreerd, ydel, veeleisend en soek voortdurend ander se goedkeuring; hulle emosies lê vlak, en hulle is meermale geneig tot seksueel verleidelike gedrag. Voorts oorreageer hierdie persoonlikheidstipes met onvanpaste oordrywing op situasies. Hulle gebruik vae taal waarin nadere besonderhede en bewyse ontbreek. Verder druk hulle emosies uit op ' $n$ dramatiese wyse (Emery \& Oltmanns, 1999:247).

Moontlike geprojekteerde manifestasies van die optrede van 'n bedienaar met hierdie afwyking kan die volgende inhou:

- Deur beklemtoning van wat ek doen en hoe ek dit doen - en hoe dinge gedoen moet word, plaas ek myself dikwels as heldefiguur in die middelpunt van die aandag op 'n byeenkoms.

- Die mense sê ons is 'n dooie kerk (geen nadere besonderhede word gegee nie).

\section{- Die obsessief-kompulsiewe persoonlikheidsdisfunksie}

Gedrag en denke word deurgaans beheers deur rigiditeit en perfeksionisme. Hierdie persoon is gepreokkupeer met die handhawing van reëls en tree wetties en veroordelend op. Die motief is 
om te presteer. Hulle vertoon die tipiese trekke van die werkolis en raak dikwels so verstrengeld in detail dat die groter geheel verlore gaan. Intellek moet gevoel, emosie en ervaring oorheers. Take word moeilik of glad nie gedelegeer nie. Sulke persone tree rigied en koppig op, "...this person resists the authority of others, but insists on his own" (Greenfield, 2001:161).

Moontlike geprojekteerde manifestasies en gedagtes van 'n bedienaar met hierdie afwyking kan die volgende wees:

- In hierdie gemeente is feitlik geen bedieningsgawes nie. Ek moet dus alles self doen.

- Die skriba skryf die notules so swak, ek moet dit altyd oordoen.

- Ek moes soveel aandag aan detail in die administrasie gee, dat ek Saterdagnag moes deurwerk om my preke te maak.

- Omdat alleen ek dinge reg kan doen, is ek die een wat besluit daaroor. Daaroor duld ek geen teenstand nie.

Die manifestasies soos hierbo genoem - en ook ander - kan daartoe lei dat die bedienaar deur sy optrede verwond.

Gemeentelede kan op verwonding reageer met dieselfde gevoelens wat die bedienaar in die eerste instansie aangevuur het om te verwond. Verwonding kan met aggressie beantwoord word. Koppigheid kan met koppigheid beantwoord word. By lidmate met 'n meer sensitiewe aard kan depressie met gevolglike onttrekking uit kerklike aktiwiteite 'n uitvloeisel wees indien hulle deur die predikant te na gekom word. Vir die opbou van die gemeente het die predikant se handelswyse van verwonding en die gemeentelede se reaksies op die verwonding negatiewe gevolge.

Dit moet hier weer gestel en beklemtoon word dat gemeentelede, wat ook beïnvloed word deur tendense in die hedendaagse kultuur en samelewing en wat ook sekere persoonlikheidsdisfunksies vertoon, ook 'n bedienaar kan verwond. Wat vir die bedienaar geld, geld ook vir die gemeente in hierdie opsig

\subsection{Samevatting van metateoretiese resultate}

- Die onmag, onvermoë en onwil van 'n bedienaar om hedendaagse kultuurtendense waaraan gemeentelede en hyself blootgestel is, te herken en te beoordeel, kan daartoe lei dat gemeentelede deur die bedienaar se gesindheid en optrede verwond en gekwets word. 
- Veral bedienaars met persoonlikheidsdisfunksies in die paranoïede, narcissistiese, histrioniese en obsessief-kompulsiewe persoonlikheidsgroeperinge, kan lidmate in die gemeente en ook buitestanders (ernstig) verwond.

\section{Praktykteoretiese perspektiewe op die bedienaar wat verwond}

\subsection{Voornemende predikante}

In sy navorsing het Kruger (2000:1) aangetoon hoe kerke in SuidAfrika reeds daartoe oorgegaan het om voornemende predikante psigometries te toets. Normaalweg is dit so dat die kuratoriums van teologiese skole indringende ondersoek instel na die roeping van toekomstige predikante, hulle gawes, suiwer leer en ook na hulle lewenswandel. Hierdie is belangrike dimensies, maar dit is nie voldoende nie.

Die Skrif self stel bepaalde gedrags- en persoonlikheidsvereistes vir 'n bedienaar. Hoe hierdie vereistes verstaan, geïnternaliseer en toegepas word deur elke voornemende teologiese student, kan deur psigometriese toetsing nader vasgestel word. Daarom het die kuratore van, onder andere, die Kweekskool in Stellenbosch (1982) en die kuratore van die Teologiese Skool in Potchefstroom (1985) besluit om omvattende psigometriese toetse in te stel vir studente wat wil inskryf vir teologiese studie om bedienaar te word. Vir hierdie studente word die volgende toetse uitgevoer: aanlegtoetse, belangstellingsvraelys, persoonlike, huislike, sosiale en formele verhoudingsvraelyste. Hierbenewens word vir psigometriese toetsing ook gebruik gemaak van die 16PF (persoonlikheidsfaktor-) vraelys; die Firo-B verhoudingsvraelys, die Belbinspanrol-vraelys, waarin onder andere gekyk word na verhoudings in die werksituasie, inpas in 'n werkstruktuur en watter rol iemand speel as hy probleme moet oplos. Voorts word ook gebruik gemaak van projektiewe tegnieke, die TAT- en Rorschach-toetsing.

Deur 'n vroeë vasstelling van bepaalde gesindhede, gawes, remminge en persoonlikheidsfaktore kan 'n voornemende bedienaar dan pastoraal en psigologies oor die hele studietydperk heen begelei word tot selfinsig en groei in gawes, optrede en gesindheid. In sekere gevalle mag dit nodig wees om op grond van sekere persoonlikheidsdisfunksies iemand aan te raai om liewer 'n ander studierigting te kies. 


\subsection{Verwonde gemeentelede}

In meer gemeentes is daar 'n kommissie van die kerkraad wat spesifiek aan die bediening in die bepaalde kerk aandag gee.

Hier word aan die hand gedoen dat so 'n kommissie se taak wyer gestel moet word as net die reël van diensbeurte as die bedienaar afwesig is. So 'n kommissie behoort 'n ontmoetingspunt te wees vir die werk van die bedienaar in die gemeente, maar ook van die gemeente se waardering, kommentaar en insette vir die bediening van die predikant. Die samestelling van so 'n kommissie moet die samestelling van die gemeente reflekteer. Kerkraadslede, lidmate uit elke leeftydsgroep, mans, vroue en jongmense behoort betrek te word in so 'n kommissie van kundiges. Die kommissie moet uit toegewyde (maar solidêr-kritiese), emosioneel volwasse en geloofsvolwasse lidmate bestaan.

Die opdrag aan so 'n kommissie is dan om lidmate wat moontlik deur die bedienaar te na gekom, gekrenk of verwond is, aan te hoor en te begelei. Aan die ander kant is dit ook die kommissie se opdrag om 'n bedienaar wat deur lidmate te na gekom en verwond is, aan te hoor en te begelei. Dit moet beklemtoon word dat so 'n kommissie nie 'n klagtekommissie is nie en dat verwonde lidmate eerstens met die bedienaar self in gesprek moet tree en 'n oplossing soek. Dieselfde geld in die geval waar 'n bedienaar verwond is.

Op so 'n wyse kan die verspreiding van gerugte en die skep van bepaalde persepsies oor verontregte gemeentelede of 'n seergemaakte bedienaar teengewerk word.

So 'n kommissie kan ook 'n versoenende taak tussen gemeentelede en die predikant fasiliteer.

Dit moet benadruk word dat die taak van so 'n kommissie ook dié is van bemoediging en beskerming van gemeentelede en bedienaar, van advies en hulp in die oplossing van probleme voordat 'n klag oor krenking of verkeerde optrede amptelik op die tafel van die kerkraad kom (vgl. Greenfield, 2002:172-177).

'n Verdere taak van die bedieningskommissie (en wyksouderlinge) kan ook begeleiding wees op die pad van vergiffenis - sowel in die geval van verontregte of gekrenkte gemeentelede en van 'n bedienaar wat te na gekom is. 


\section{3 'n Predikant wat houe uitdeel}

Dit moet sterk in gedagte gehou word dat 'n predikant wat houe uitdeel en mense deur sy houding en optrede te na kom, vanuit die Woord van God pastoraal begelei moet word. Hierdie begeleiding sluit vertroosting en vermaning in. Indien nodig, kan nader ingegaan word op die konkrete toepassing van die Bybelse vereistes vir 'n bedienaar in sy optrede teenoor lidmate. Besondere klem behoort in die begeleiding geplaas te word op die aard en diepgang in die bedienaar se persoonlike verhouding met God soos dit na vore kom in die eie omgang met die Skrif en die bepeinsing van die Skrif. Ook die persoonlike gebedslewe kan as tema dien in die pastorale begeleiding.

Daar mag 'n tyd kom dat 'n kommissie of kerkraad 'n bedienaar wat aanhou om die gemeente as teiken te gebruik moet verwys vir verdere diagnose en hulp in die hantering van disfunksionele patrone in sy persoonlikheid en optrede.

Meermale besef ' $n$ bedienaar self nie die probleme nie. Juis daarom kan verwysing nodig wees om te begelei tot meerdere selfinsig. Die 16 PF-toets is maar een wat gebruik word om psigologiese afwykings op te spoor; so ook die DSM IV-handleiding. 'n Simpatieke, gelowige sielkundige of waar nodig 'n psigiater, kan 'n instrument wees om 'n bedienaar wat houe uitdeel, mense krenk of te na kom, te begelei tot 'n bedienaar wat genees.

Bowenal het 'n bedienaar wat deur sy gedragswyse en optrede verwond (én sy huisgesin) medegelowiges se besoek, Woordbediening en voorbidding intens nodig.

Die Heilige Gees alleen genees wonde - van sowel gemeentelede as van bedienaars. Albei partye bly in finale instansie voorwerpe van God se reddende genade en die gemeente se sorg.

\section{Geraadpleegde bronne}

ARMSTRONG, R.S. 1990. The pastor-evangelist in the parish. Westminster: John Knox

BASSLER, J.M. 1996. 1 Timothy, 2 Timothy, Titus. Nashville: Abington.

BAUER, W. 1979. A Greek-English Lexicon of the New Testament and other early Christian literature. Chicago: Chicago University Press.

CILLIERS, J.H.J. 2004. Pastoraat aan adolessente wat by okkultiese subkulture betrokke is - 'n pastoraal-terapeutiese benadering. Bloemfontein: Universiteit van die Vrystaat. (Ph.D-proefskrif.)

CLEMENTS, R. 1998. Expository preaching in a postmodern world. Foundations, 40:10-17. 
DSM-IV-TR, 2000. Diagnostic and statistical manual of mental disorders - IV Edition - text revision. Washington: American Psychiatric Association.

DE WET, F.W. \& VENTER, C.J.H. 2001. Aangegryp deur die Woord teologies-estetiese riglyne vir die omgang met en bediening van die Woord. Acta Theologica, 21(2):23-35.

DREYER, Y. 2003. Beyond psychology: spirituality in Henri Nouwens' pastoral care. Hervormde Teologiese Studies, 59(3):715-733.

EMERY, R.E. \& OLTMANNS, T.F. 1999. Essentials of abnormal psychology. New Jersey: Prentice Hall.

GREENFIELD, G. 2001. The wounded minister. Grand Rapids: Baker.

JACKSON, N. 2002. Broers en susters ... Insig: 38-41, Junie.

JANG, J.Y. 2003. Expository preaching. A homiletical study in the light of Acts 2 and 17. Potchefstroom: PU for CHE. (M.A. dissertation.)

JOHNSTON, G. 2001. Preaching to a postmodern world: a guide to reaching twenty-first-century listeners. Grand Rapids: Baker.

KIM, H.K. 1997. Preacher and spirituality. A diaconiological study in the light of the Pastoral Epistles. Potchefstroom: PU vir CHO. (Th.M dissertation.)

KRUGER, F.P. \& VENTER, C.J.H. 2000. Prediker, preekgesindheid en die toerusting van die gemeente. In die Skriflig, 34(2):173-194.

KRUGER, S.F. 2000. Menslike persoonlikheid en toerustende herderlike bediening. Aspekte van 'n metateorie, basisteorie en praktykteorie. Potchefstroom: PU vir CHO. (Th.D -proefskrif.)

KRUGER, S.F. 2004. Verandering in die kerk. Maak seker jy verstaan dit. Middelburg Mp: Outeur.

KRUGER, S.F. \& VENTER, C.J.H. 2004. Die predikant as teiken - profiel van iemand wat emosionele wonde toedien. In die Skriflig, 38(3):451-476.

LOUW, D.J. 1997. 'n Diagnostiese model vir die assessering van spiritualiteit met die oog op geloofsontwikkeling in die pastorale bediening. Praktiese Teologie in Suid-Afrika, 12(2):11-25.

LUTZER, E. 1998. Pastor to pastor. Tackling the problems of ministry. Grand Rapids: Kregel.

MONTOYA, A. 2000. Preaching with passion. Grand Rapids: Kregel.

NEL, M. 2001. Ek is die verskil. Die invloed van persoonlikheid in die prediking. Bloemfontein: CLF.

QUINN, J.D. \& WACKER, W.C. 2000. The first and second letters to Timothy. Grand Rapids: Eerdmans.

RIENECKER, R. 1980. A linguistic key to the Greek New Testament. Vol. 2. Grand Rapids: Zondervan.

ROSSOUW, G.J. 1993. Theology in a postmodern culture. Hervormde Teologiese Studies, 49(4):894-907.

STOTT, J.R.W. 1997. The message of Timothy and Titus. Leicester: InterVarsity.

TEMPELHOFF, E . 2002. Herderlose herders. Insig: 42, Junie.

TOWNER, P.H. 1994. 1-2 Timothy \& Titus. Ilinois: InterVarsity.

VENTER, C.J.H. 1976. Die bediening van die versoening aan die bejaarde. 'n Pastorale studie in die lig van die Pastorale Briewe. Potchefstroom: Pro Rege.

VENTER, C.J.H. 1999. Die spiritualiteit van die bedienaar met verwysing na sy toerustingstaak. In die Skriflig, 33(2):187-202, Junie. 
VENTER, C.J.H. 2003. Die prediking van hoop aan getraumatiseerdes in die huisgesin van God. Praktiese-teologies perspektiewe in die lig van Hebreërs. In die Skriflig, 37(1):27-50, April.

VORSTER, J.M. 1999. 'n Waarskynlike bedieningsmilieu vir die GKSA in die dekades na 2000. In die Skriflig, 33(1):99-119.

WILLHITE, K. 2001. Preaching with relevance. Grand Rapids: Kregel.

\section{Kernbegrippe:}

bedienaar - pastorale begeleiding gedragspatrone - negatiewe manifestasies persoonlikheidstipes - toegespits op die optrede van die predikant

\section{Key concepts:}

behavioural patterns - negative manifestations pastor - pastoral guidance personality types - focused on the attitude of the minister 
